\title{
Lynn Vavreck: \\ The Message Matters \\ - The Economy and Presidential Campaigns. Princeton: Princeton University Press. 2009.
}

\author{
Anders B. Rasmussen
}

MedieKultur 2010, 49, 187-189

Published by SMID | Society of Media researchers In Denmark | www.smid.dk The online version of this text can be found open access at www.mediekultur.dk

Lynn Vavreck's campaign theory is simple. Perhaps it is a little too simple, in fact. But it is certainly thought-provoking.

The economy determines an American presidential election's outcome. If the economy is strong, the incumbent party retains power. If the economy is faltering, the administration will change. This trend can be reversed, however, if the candidate facing an economic headwind chooses the right campaign message and uses it effectively.

Vavreck, a young American political scientist from UCLA, Begins her work with a historiographic review of the most significant election studies over the last 65 years. In doing so, Vavreck lays bare a long tradition of election research with great focus on the economy's impact, and very little focus on the meaning of campaign messages themselves. It is here that Vavreck's contribution is most compelling.

At times, candidates with the economy seemingly working in their favour manage to lose elections anyway. This happened to Richard Nixon in 1960 against John Kennedy. It happened to Hubert Humphrey against Nixon in 1968, it befell Gerald Ford in 1976 against Jimmy Carter, and Al Gore also managed to lose to George W. Bush in 2000 despite the economy favouring his party.

According to Vavreck, the right election theme from a candidate running in a perilous economic climate can help offset the opponent's natural advantage on the economy. Instead of focusing on a favourable economy under Republican rule, Nixon in 1960 chose to make foreign policy the main focus of his presidential campaign. This opened the door 
for Kennedy to talk about the national decline of schools, housing, welfare and the space programme. Kennedy's persistence in hammering home the domestic problems faced, and perpetuated, by the previous Republican administration was, according to Vavreck, the key to victory. Especially since, Vavreck convincingly demonstrates, the same non-economic issues were subsequently applied by Nixon, Carter and Bush alike.

Rooted in Anthony Downs' "spatial voter model" and a major content analysis (with convincing intercoder-reliability) coupled with interviews conducted by the American National Election Study (ANES), Vavreck's study examines the themes employed by 15 presidential election campaigns. Before she even gets to the campaigns, however, Vavreck works her way through 895 TV election advertisements, 2517 election speeches and 956 New York Times election articles. This study provides interesting results on a number of fronts.

First of all, it turns out that predictions about presidential election outcomes become far more precise when models, previously only based on economic variables, also account for the candidates' election message. Second of all, Vavreck convincingly demonstrates that the New York Times is more focused on framing articles dramatically than on what the candidates are trying to tell the voters. This conclusion leads to a third important point: voters learn more about the candidates' standpoints through TV advertisements than through the media or candidates' speeches.

However, the book's 166 pages are so tightly focused on the theoretical foundation, content analysis and ANES interviews that the reader is left with a few questions.

The most obvious question is why Vavreck only once utilises "third-party" candidates as a partial explanatory variable for election outcomes. In Vavreck's view, all elections can be explained by economy and election messages, but Ross Perot's garnering of $19 \%$ of the popular vote in 1992 is never given credence within the framework of the study. The same is true for John B. Anderson's candidacy in 1980 and Ralph Nader's potential influence on the 2000 election.

In light of Vavreck's all-or-nothing focus on economy and election themes, it is relevant to ask how conscious the candidates actually are of the election-typology into which Vavreck tries to squeeze them. For example, "Candidates seem to understand" and "Clinton and Carville probably knew this," (p. 113, p. 134) but she never explicitly argues that the candidates were actually aware of their campaign messages' importance in relation to the economy and the opponents' disadvantages. The fact that 11 out of 15 candidates running against the economic current lost the election either indicates that the economy is the universal decisive factor, or that the candidates do not know which election message to choose to be competitive in an economic headwind. An analysis of the candidates' letters, diaries, memoirs or personal interviews could have shed more light on this part of her theory.

As a reader, one also wonders whether or not Vavreck's link between the New York Times' political coverage and the electorate's political attitudes is valid. Seemingly, there are at least three potential problems. First, the New York Times becomes a proxy for all American news outlets in the analysis. Second, all potential voters are thereby assumed to 
read the New York Times when their political attitudes are included in the analysis. Lastly, Vavreck places enormous emphasis on TV advertisements as an explanatory variable connected with the electorate's attitudes, but at no point does she include an analysis of the TV newscasts during which these campaign ads are aired.

Finally, at a time when comparative media and election studies are generating great enthusiasm in the academy, it is interesting to note that Vavreck chooses to situate her analysis in a long tradition of ethnocentric scholarship. The scope of the study is thus delimited and one wonders how applicable its findings are outside U.S. borders.

These four points should not, however, overshadow the fact that Vavreck's book is an interesting and very readable contribution for people with an interest in media and election studies. The themes candidates use within American election cycles are now much better illuminated and Vavreck opens the door for a host of exciting analyses that will likely be built on The Message Matters' foundation.

Vavreck concludes that: "The economy is the backdrop in front of which the great play of modern presidential campaigns is performed. The scenery is important. But as Shakespeare said, 'the play's the thing."' Yet, even at the end of the play, the reader is still left with a suspicion that election campaigns cannot be explained quite so neatly.

Anders B. Rasmussen

PhD student

Centre for Journalism

University of Southern Denmark, Denmark

ras@sam.sdu.dk 